\title{
POTENTIAL OF ENTOMOPATHOGENIC NEMATODES FOR CONTROL OF THE ERVA-MATE PEST Hedypathes betulinus (KLUG, 1825) (COLEOPTERA: CERAMBYCIDAE)
}

\author{
Viviane Sandra Alves ${ }^{1 *}$, Luis Francisco Angeli Alves ${ }^{2}$, André Luis Pereira Fanti $^{3}$, Marilia de Souza Alves ${ }^{4}$ \\ ${ }^{1 *}$ Universidade Estadual do Norte do Paraná, Programa de Mestrado em Agronomia, Cornélio Procópio, Paraná, Brasil - \\ vivialves@uenp.edu.br \\ ${ }^{2}$ Universidade Estadual do Oeste do Paraná, Programa de Pós-Graduação em Conservação e Manejo de Recursos Naturais, Cascavel, \\ Paraná, Brasil - luis.alves@unioeste.br \\ ${ }^{3}$ Universidade Estadual do Oeste do Paraná, Cascavel, Paraná, Brasil - andre.fanti@ gmail.com \\ ${ }^{4}$ Universidade Estadual do Norte do Paraná, Cornélio Procópio, Paraná, Brasil - marilialvez@ hotmail.com
}

Received for publication: 04/09/2015 - Accepted for publication: 19/12/2016

\begin{abstract}
The intensive exploitation of "erva mate" (Ilex paraguariensis St. Hil.) (Aquifoliaceae) has favored the emergence of pests, including Hedypathes betulinus. We evaluated 18 isolates of entomopathogenic nematodes Steinernema and Heterorhabditis genera for control of H. betulinus adults, and tested nematode in-vivo replication capacity in Galleria mellonella L. (Lepidoptera: Pyralidae) larvae. We also evaluated the effect of adjuvants for foliar application, and the efficiency of nematode isolates selected in erva mate seedlings in the greenhouse via application to soil and plant shoots. The PI and CB40 isolates showed the hgh virulence ( $92.5 \%$ insect mortality by both). The PI isolate showed low productivity in G. mellonella larvae, thus only CB40 was used in subsequent tests. Only emulsified vegetable oil adjuvant was compatible with nematodes. Soil application of nematodes proved ineffective; however, shoot application on erva mate seedlings showed significant mortality (82.5\%) after exposure to the CB40 isolate without adjuvant.

Keywords: Steinernema, Heterorhabditis, Ilex paraguaiensis, biological control.
\end{abstract}

\section{Resumo}

A exploração intensiva da erva-mate (Ilex paraguariensis St. Hil.) (Aquifoliaceae), tem favorecido o surgimento de pragas incluindo a broca-da-erva-mate (Hedypathes betulinus). Visando seu controle avaliouse a virulência de 18 isolados de nematoides entomopatogênicos dos gêneros Steinernema e Heterorhabditis sobre adultos do inseto e a capacidade de multiplicação in vivo dos nematoides em larvas de Galleria mellonella L. (Lepidoptera: Pyralidae). Foi avaliado também o efeito de adjuvantes foliares e a eficiência dos nematoides selecionados sobre o inseto, em mudas de erva-mate, em casa de vegetação, com aplicação no solo e na parte aérea das plantas. Os isolados PI e CB40 foram os de maior virulência sobre o inseto (92,5\% de mortalidade, para ambos), porém o isolado PI mostrou-se pouco produtivo em larvas de G. mellonella e apenas o isolado CB40 foi usado nos testes subsequentes. Dentre os adjuvantes avaliados, somente o óleo vegetal foi compatível com o nematoide. No teste em casa-de-vegetação com aplicação no solo não foi observada mortalidade dos insetos. A aplicação na parte aérea das mudas de erva-mate apresentou efeito significativo, em relação à testemunha, sendo que com o isolado CB40 aplicado sem adjuvante obteve-se mortalidade de $82,5 \%$.

Palavras-chave: Steinernema, Heterorhabditis, Ilex paraguaiensis, Controle Biológico.

\section{INTRODUCTION}

Erva mate Ilex paraguariensis Saint Hil. (Aqüifoliaceae) plants are native to southern and midwestern Brazil, Paraguay, and Argentina. Changing in erva mate to monoculture production has increased the productivity, and in Brazil erva mate annual production is estimated approximately in 252,700 tons, concentrated in the states of Brazilian south region (Paraná, Santa Catarina and Rio Grande do Sul states) (IBGE, 2013). Monoculture production in Brazil also favors the occurrence of pests, especially Hedypathes betulinus (Klug, 1825) (Coleoptera: Cerambycidae), named "broca da erva-mate" (PENTEADO et al., 2000; BORGES et al., 2003). Adults live in the shoot, and mate and lay eggs near the base of the plant, on the branches and in bark crevices (CASSANELLO, 1993; GALILEO et al., 1993; D'AVILA et al., 2006). Resident larvae are responsible for the damage, by building galleries on branches and longitudinally along the trunk, preventing sap movement 
and weakening the plant. In the case of severe infestations or successive pest generations on the plant, death may occur (SOARES, 1998; GUEDES et al., 2000).

Entomopathogenic fungi have been found in natural epizootics association with $H$. betulinus (SOARES et al., 1995; SOARES and IEDE, 1997; LEITE et al., 2000; LEITE et al., 2006). Also, many studies were carried out with isolates selection in the laboratory and in field evaluation (SOARES; IEDE, 1997 MILK et al., 2000 BORGES, 2007; GOMM, 2010, FANTI; ALVES, 2013). These studies resulted in a product based on the fungus Beauveria bassiana (Bovemax ${ }^{\circledR} \mathrm{EC}$ ) that has since been registered for commercial use in integrated pest management (AGROFIT, 2015). Entomopathogenic nematodes (EPNs) Mermithidae have also been found in association with the pest in the field. However, due to some biological characteristics of this nematode family, there is little potential for their use in controlling $H$. betulinus.

Alves et al. (2009a) in a pioneer study demonstrated the susceptibility of $H$. betulinus to the nematodes genus Steinernema, in which pests reached $80 \%$ mortality within 10 days after treatment. The biology of the pest includes the female behavior of approaching the base of the plant (close to the ground) to oviposit, in which case nematodes present in soil may be control of the pest. Among the advantages of EPNs is their ability to search for hosts, and their symbioses with bacteria, which effectively kills insects. Moreover, in addition to killing the host quickly these agents are not harmful plants or vertebrates, are selective for insects, do not pollute soil or groundwater, are safe for the producers, and can readily establish the ground to maintain long-lasting, small populations to fight pests (FERRAZ, 1998; VOSS et al., 2009).

A successful biological control program depends on the existence of efficient control agents both under laboratory and in the field conditions, and in the case of $H$. betulinus, such products are rare, highlighting the need to search for new alternatives. This study aimed to evaluate and select isolates of EPNs to control $H$. betulinus, specifically those showing virulence and high productivity, as well as efficiency in semi-field conditions after soil and leaf application.

\section{MATERIALS AND METHODS}

\section{Collection of nematodes and insects:}

H. betulinus adults were obtained from a commercial erva mate plantation located in Ivaí, Paraná, Brazil. The insects were collected and kept in cages $(60 \mathrm{~cm} \times 40 \mathrm{~cm}$ wide $\times 40 \mathrm{~cm}$ long) containing erva mate branches and under controlled conditions $\left(26 \pm 1{ }^{\circ} \mathrm{C}, 70 \%\right.$ relative humidity, $14 \mathrm{~h}$ photophase) until experiments began, and not exceeding seven days (ALVES, 2009a). Prior to beginning experiments intact insects were selected with movement and normal responses to stimuli (SOARES, 1998). We evaluated 18 isolates of Steinernema and Heterorhabditis nematodes from different research institutions in Brazil, reared in $G$. mellonella larvae as follows.

\section{Selection of nematode isolates:}

We uses 40 plastic $500 \mathrm{ml}$ containers divided into four replications, each containing erva mate branches for food and closed with perforated plastic covers and lined with 150g of moist sand (Alves et al., 2009a).

Nematode suspensions were applied to dry sand (100 Infective Juveniles (IJs)/ $/ \mathrm{cm}^{2}$ ) (surface area). After application of the suspension, sterile distilled water it was added to obtain $20 \%$ substrate moisture. The adults insects were then released onto the branches (one insect/container). For controls, the sand was treated with distilled water (20\% moisture).

The containers were closed and maintained at $26 \pm 1{ }^{\circ} \mathrm{C}$ with $14 \mathrm{~h}$ photoperiod. Measurements were made daily for 15 days, and dead insects were transferred into a dry chamber composed of Petri dishes lined with dry filter paper where they remained for five days. After this time, $2 \mathrm{ml}$ of distilled water was applied to the paper surface, and after $24 \mathrm{~h}$ the cadavers were dissected and observed under stereomicroscope to search for nematodes. Isolates causing at least $80 \%$ mortality were selected for the next step.

\section{Estimation of CL99 of isolate CB40 and in vivo production in Galleria mellonella larvae:}

Nematode suspensions were inoculated into Petri dishes $(9 \mathrm{~cm} \mathrm{dia.}$.) lined with two sheets of filter paper at concentrations of $0,500,1000,1500,2000$ and $2500 \mathrm{IJs} /$ plate; $10 \mathrm{G}$. mellonella larvae were placed on each dish. Dished were incubated at $26 \pm 1^{\circ} \mathrm{C}$, with $70 \pm 10 \% \mathrm{RH}$ and a $14 \mathrm{~h}$ photophase. Control dishes were treated only with distilled water. After 72 hours post-treatment, dead larvae were transferred into a dry chamber and maintained for five days to confirm nematode infection as described above. Each plate was considered one replicate, with a total of five replicates carried out per nematode concentration. The results were analyzed by linear regression using Excel 2007. After that, in vivo production it was evaluated. Therefore, $2 \mathrm{ml}$ of a nematode suspension were inoculated onto Petri dishes lined by filter paper $(630 \mathrm{IJs} /$ plate). Ten previously weighed (lab 
reared) G. mellonella larvae were placed on the dish. Dishes were covered and sealed with plastic film, and incubated at $24 \pm 1{ }^{\circ} \mathrm{C}$ in the dark for 72 hours. After confirmation of death, cadavers were transferred into a dry chamber and maintained for five days at $24 \pm 1^{\circ} \mathrm{C}$ after which nematode infection was confirmed (WOODRING; KAYA, 1988). After five days, the larvae were transferred to White traps for emergence of the IJs, which were collected and quantified daily until production ended. The most productive strain was selected for the next step.

\section{Effect of adjuvants with CB40 isolates:}

We evaluated the effect of foliar fertilizer TEK-F $\mathrm{F}^{\circledR}$ and Aureo ${ }^{\circledR}$ vegetable oil emulsifiable on the CB40 isolate for future application under field conditions. We used the IOBC protocol adapted by Negrisoli et al. (2008), in which a solution of the product is prepared with distilled water at double the dose recommended by the manufacturers. One $\mathrm{mL}$ of solution is then transferred to a glass tube, followed by $1 \mathrm{~mL}$ of the CB40 nematode suspension $(2000 \mathrm{IJs} / \mathrm{mL})$, yielding the product concentration indicated by the manufacturer. For controls, $1 \mathrm{~mL}$ of nematode suspension was added to $1 \mathrm{~mL}$ of distilled water. Five replicate tubes were prepared for each treatment. The tubes were kept at $22 \pm 1{ }^{\circ} \mathrm{C}$ with $14 \mathrm{~h}$ photoperiod for $48 \mathrm{~h}$, after which the viability and infectivity of the isolate was evaluated. Data were subjected to ANOVA (the experiment having a completely randomized design) and means were compared by Tukey test $(\mathrm{p}<0.05)$ using the statistical program Sisvar (FERREIRA, 2011).

\section{Greenhouse experiment with erva-mate seedlings:} follows.

The CB40 isolate was applied to the aerial parts of the plants (foliar application) and to the soil, as

\section{Foliar application:}

CB40 isolate was multiplied in vivo (see in vivo methods above) and stored in aqueous suspension, maintained with aeration to prevent sedimentation and death of IJs. Erva-mate seedlings $(\sim 50 \mathrm{~cm}$ height $)$ were kept in pots and individually placed in wooden cages $(55 \times 40 \times 40 \mathrm{~cm})$ lined with nylon mesh. Ten adult insects were released in each cage, and the nematode suspension was applied throughout the shoot with manual spray to the point of run-off (approximately $14 \mathrm{~mL}$ of suspension/plant containing $5.0 \times 10^{-3} \mathrm{IJs} / \mathrm{mL}$ ). Treatments consisted of CB40 nematode suspension in distilled water, CB40 + Aureo ${ }^{\circledR}$, nematode suspension, and Aureo ${ }^{\circledR}$ solution (both treatments with Aureo ${ }^{\circledR}$ following manufacturer recommendations). Control seedlings were treated with distilled water. Treatments were replicated four times. Five days after application, dead insects were counted and transferred to a dry chamber for confirmation of mortality, as described above. Data were subjected to analysis of variance ( $F$ test) and means compared by Tukey test ( $p$ <0.05) according to a completely randomized experimental design using the statistical program Sisvar (FERREIRA, 2011).

\section{Soil application:}

Application to soil followed the same experimental procedures and statistical analysis described above, except that nematodes were applied directly to soil at a concentration of $100 \mathrm{IJs} / \mathrm{cm}^{2}$ using a $10 \mathrm{~mL}$ pipette, and five $H$. betulinus adults were released onto the shoot. After five days, dead insects were counted and placed in a dry chamber for 5 days, then dissected to confirm mortality.

\section{RESULTS AND DISCUSSION}

\section{Selection of nematode isolates:}

There was strong variation in results, with only two out of 18 isolates causing mortality above $90 \%$ (CB40 and PI, both belonging to the genus Heterorhabditis). The CH3 isolated, SA, NEPET 11 and CB02 caused between 55 and $75 \%$ mortality, while the others caused less than $50 \%$ mortality (Table 1).

It's known both among and within-species differences in insect susceptibility to nematode genus (VAN TOL et al., 2004; VAN TOL; RAUPP, 2006; ALVES et al, 2009b). For example the CB40 and PI isolates both belonging to the genus Heterorhabditis, yet it is also impossible to affirm that this genus best suited to $H$. betulinus since other isolates in the genus showed very little activity.

Variation in cerambycid susceptibility to different nematode species and isolates has been previously reported. Machado et al. (2003) by selected EPNs for control of Migdolus fryanus (Westwood, 1863) (Coleoptera: Vesperidae) larvae and observed high susceptibility to genus Heterorhabditis, with up to $100 \%$ mortality. On the other hand, for Plectrodera scalator (Fabr., 1792) (Coleoptera: Cerambycidae) larvae with only S. carpocapsae All and S. feltiae SN isolates it was obtained mortality higher than 50\%, and high concentrations were required to cause significant insect mortality (FALLON et al., 2006). Harvey et al. (2012) 
evaluated the potential of S. carpocapsae and H. downesi for control of Rhagium bifasciatum Fabr., 1775 (Coleoptera: Cerambycidae) and found that both nematodes were capable of infecting larvae, pupae and adults both in laboratory and field conditions.

Table 1. Mortality in Hedypathes betulinus adults caused by entomopathogenic nematodes under laboratory conditions.

Tabela 1. Mortalidade de adultos de Hedypathes betulinus causada por nematoides entomopatogênicos em condições de laboratório.

\begin{tabular}{|c|c|c|c|}
\hline Isolate & Genus/Species & Location & $\%$ Mortality \\
\hline NEPET 8 & Heterorhabditis sp. & Origin unknown & 0.0 \\
\hline CB36 & Steinernema sp. & Naviraí - MG - Brazil & 0.0 \\
\hline SORGO & Heterorhabditis sp. & Lavras - MG - Brazil & 0.0 \\
\hline $\mathrm{RSC0} 2$ & Heterorhabditis sp. & Benjamin Constant - AM - Brazil & 17.8 \\
\hline JPM3 & Heterorhabditis sp. & Lavras - MG - Brazil & 19.3 \\
\hline CB44 & Heterorhabditis sp. & Santa Adélia - SP - Brazil & 22.0 \\
\hline RSC01 & Heterorhabditis sp. & Benjamin Constant - AM - Brazil & 33.3 \\
\hline RSC05 & H. amazonensis & Benjamin Constant - AM - Brazil & 36.6 \\
\hline ALHO & Heterorhabditis sp. & Lavras - MG - Brazil & 37.5 \\
\hline JPM4 & Heterorhabditis sp. & Lavras - MG - Brazil & 44.8 \\
\hline NEPET 36 & Heterorhabditis sp. & Origin unknown & 45.0 \\
\hline HP88 & H. bacteriophora & New Jersey - USA & 46.8 \\
\hline $\mathrm{CH} 3$ & Steinernema sp. & Campinas - SP - Brazil & 55.0 \\
\hline SA & S. arenarium & North Carolina - USA & 68.7 \\
\hline NEPET 11 & Heterorhabditis sp. & Palmeiras das Missões - RS - Brazil & 75.0 \\
\hline CB02 & S. carpocapsae & Florida - USA & 75.0 \\
\hline CB40 & Heterorhabditis sp. & Taboporã - SP - Brazil & 92.5 \\
\hline PI & Heterorhabditis sp. & Terezina - PI - Brazil & 92.5 \\
\hline
\end{tabular}

These data reinforce the need to carefully select entomopathogenic nematode isolates, because biological features and adaptations to the environment can cause great variation among species, and even among isolates of the same species (GAUGLER et al., 1997). Our results demonstrate this variability, and the importance of conducting tests in order to choose the most appropriate isolate for insect control. So, CB40 and PI isolates were selected to continue the research.

Estimation of CL99 of isolate CB40 and in vivo production in Galleria mellonella larvae:

The PI isolate showed low productivity, requiring a large number of hosts to obtain a small number of individuals, and thus, it was discarded at this stage of the study. The $\mathrm{CL}_{99}$ of isolate CB40 in G. mellonella larvae was estimated at $9 \mathrm{IJs} / \mathrm{cm}^{2}$, which is considered low and indicative of high virulence (Figure 1).

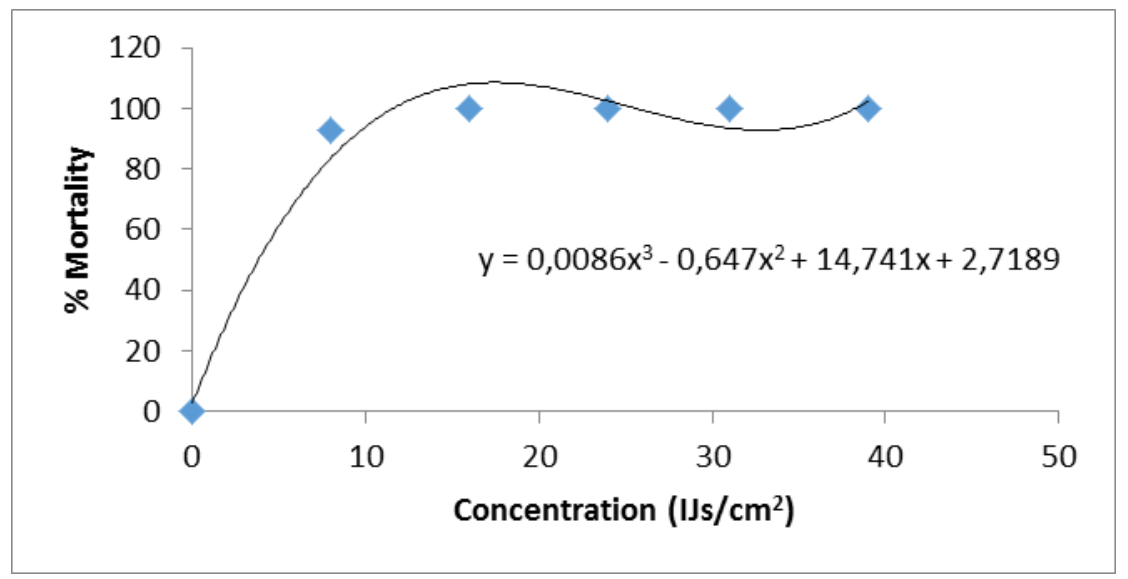

Figure 1. Mortality of Galleria mellonella 72 hours after exposure to CB40 isolates of different concentrations. Figura 1. Mortalidade de Galleria mellonella após 72 horas de esposição ao isolado CB40 em diferentes concentrações. 
Barbosa (2005) show an estimated $\mathrm{CL}_{99}$ of $43 \mathrm{IJ} / \mathrm{cm}^{2}$ for H. bacteriophora in G. mellonella larvae. G. mellonella has high susceptibility to most known entomopathogenic nematodes, and it can also be assumed that smaller nematodes can penetrate hosts with greater ease, which may have been a factor in the virulence of isolate CB40. Further, CB40 Heterorhabditis are able to penetrate not only natural openings of hosts, but also the cuticle (GIOMETTI, 2011); this is another feature that may be associated with virulence of this isolate.

About in vivo production, CB40 IJs emerged from G. mellonella larvae for up to 10 days, with peak emergence between the third and fourth days. The total accumulated production in the host was $6.5 \times 10^{4}$ IJs/larva or $4.2 \times 10^{4} \mathrm{IJs} / \mathrm{g}$ larva (Figure 2 ).

The results obtained are lower than previously reported in studies with different isolates in $G$. mellonella, including Barbosa (2005), which report $4.9 \times 10^{5} \mathrm{IJs} / \mathrm{g}$ larva for $H$. bacteriophora.

Saenz and Lopes (2011) also evaluated the production of Heterorhabditis sp. isolate SL0708 and obtained between 1.5 and $2.8 \times 10^{5} \mathrm{IJ} /$ /larva. According to the authors, the differences in the production of IJs in G. mellonella are due to various factors involved in the infection process, including the host penetration site (mouth, anus, spiracles or cuticle), inoculum concentration, the number of IJs infecting the host, and the local release of symbiotic bacteria in the hemolymph, all of which can interfere with $\mathrm{J} 1$ development within the host. The $\mathrm{CL}_{99}$ of our CB40 isolate is quite low by comparison, which may have been a factor affecting productivity. This indicates the need to evaluate other inoculum concentrations for improved productivity.

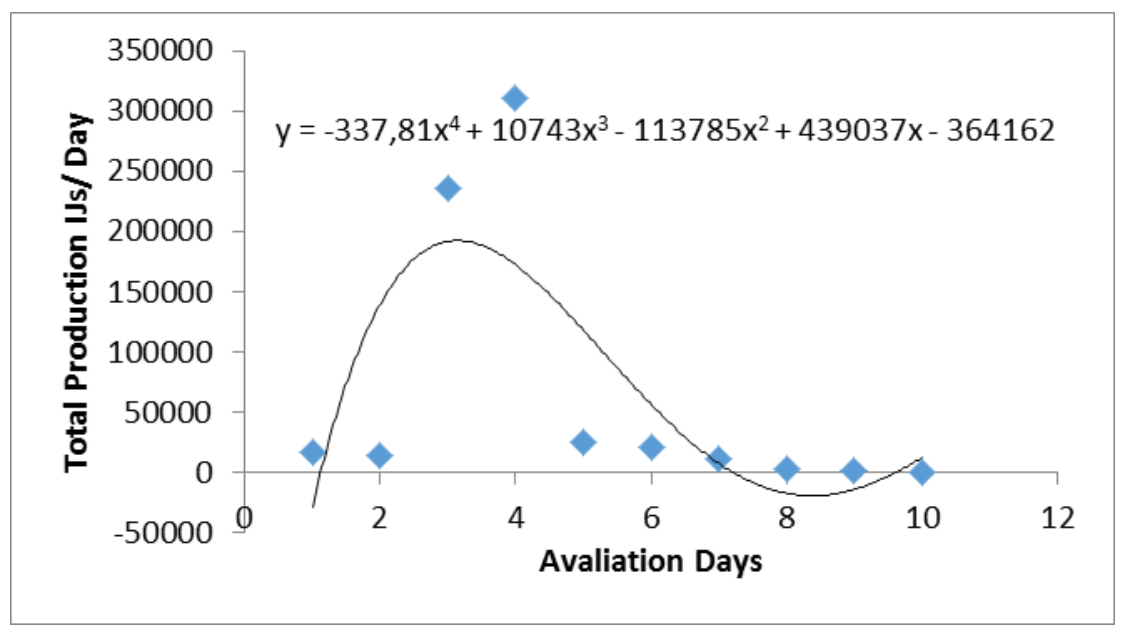

Figure 2. Production of CB40 infectious juveniles in Galleria mellonella.

Figura 2. Produção de juvenis infectantes do isolado CB40 em Galleria mellonella.

\section{Effect of formulation adjuvants isolated on CB40:}

The TEK-F ${ }^{\circledR}$ product significantly reduced the viability and infectivity (by 84 and $82 \%$, respectively) and is classified as incompatible with CB40 according to the IOBC protocol. The Aureo ${ }^{\circledR}$ product vegetable oil base did not affect the viability or infectivity of nematodes and results did not differ from the controls, highlighting the possibility of joint use of this product and the nematode (Table 2).

Table 2. Viability and infectivity (mean \pm SE) of CB40 isolate infective juveniles (Heterorhabditis sp.) after exposure to adjuvants, and their compatibility.

Tabela 2. Viabilidade e infectividade (média \pm DP) de juvenis infectantes do isolado CB40 (Heterorhabditis sp.) após exposição aos adjuvantes, e sua compatibilidade.

\begin{tabular}{lllll}
\hline Treatment & \% Viability & Classification* & \% Infectivity & Classification \\
\hline CB40 (Control) & $93.2 \pm 1.50 \mathrm{~A}^{* *}$ & - & $52.0 \pm 8.60 \mathrm{AB}$ & - \\
CB40+Aureo ${ }^{\circledR}$ & $87.4 \pm 0.98 \mathrm{~A}$ & Compatible & $78.0 \pm 5.83 \mathrm{~A}$ & Compatible \\
CB40+TEK-F $^{\circledR}$ & $16.4 \pm 6.38 \mathrm{~B}$ & Incompatible & $18.0 \pm 7.35 \mathrm{~B}$ & Incompatible \\
\hline CV. & 10.88 & & 39.34 & \\
\hline
\end{tabular}

* Product classification according to IOBC protocol (VAINIO, 1992).

***Different letters in columns indicate significant differences between treatment groups (Tukey test, $\mathrm{P} \leq 0.05$ ).

\section{Greenhouse experiment - soil application:}

The isolate showed promising results in the laboratory, causing over $90 \%$ mortality in the insects, and presented ease of in vivo production in G. mellonella larvae, however it did not show activity against $H$. 
betulinus when applied to the soil. This may have been due to the surface available on the plant for the insect to remain upon, perhaps decreasing the chance of contact with the soil and consequently, with the nematode.

\section{Greenhouse experiment - foliar application:}

Foliar application caused $82.5 \%$ mortality of insects treated with nematodes in pure suspension, with no increased nematode action when combined with adjuvant. Furthermore, although the product does not have toxicity to IJs, it is toxic to insects (Table 3).

Bellini and Dolinski (2012) evaluated foliar application efficiency of $H$. baujardi (LPP7 isolate) and $S$. carpocapsae (Ncall isolate) for control of Diatraea sacharalis under greenhouse conditions, with and without adjuvants similar to those used in this study (Joint* Oil- Dow AgroSciences and Gotafix ${ }^{\circledR}$ - Milenia) and as in our study, found no differences between treatments.

Table 3. Mortality (mean $\pm \mathrm{SE}$ ) of Hedipathes betulinus after spraying CB40 isolate under greenhouse conditions.

Tabela 3. Mortalidade (média \pm DP) de Hedipathes betulinus após aplicação do isolado CB40 em condições de casa-de-vegetação.

\begin{tabular}{ll}
\hline Treatment & \% Mortality \\
\hline Control & $7.3 \pm 7.14 \mathrm{~A}^{*}$ \\
CB40 nematodes + Aureo $^{\circledR}$ & $46.3 \pm 6.00 \mathrm{~B}$ \\
Aureo $^{\circledR}$ & $58.5 \pm 6.98 \mathrm{BC}$ \\
CB40 nematodes & $82.5 \pm 11.09 \mathrm{C}$ \\
\hline
\end{tabular}

** Different letters indicate significant differences between treatment groups (Tukey test, $\mathrm{P} \leq 0.05$ ).

While foliar application of EPNs is somewhat unusual, the literature does support the action of some isolates capable of infecting cerambycid larvae while still inside the stem of infected plants (FINNEY; WALKER, 1977; FINNEY; WALKER, 1979; SOLTER et al., 2001), suggesting its potential as a strategy for controlling this pest. Further, Fallon et al. (2004) evaluated control methods for Anoplophora glabripennis and showed that nematode isolates may have capacity for to move, attracted by host presence or host excrement, which serve as a stimulus for localization of larvae or even adult insect hosts in the plant, enabling application on aerial parts of the plant or areas of trunk infested with larvae. In the case of the $H$. betulinus, the adult remains most of the time in the aerial region of the plant and females moving to inferior part of the plants only to oviposit within the branches, making control on leaf areas important; this study indicates foliar application as a viable method of control. Another alternative would be to use EPNs in conjunction with other control measures, such a insect sex pheromone traps if identified (FONSECA et al., 2010), which would enhance insect encounter with effective nematodes.

\section{CONCLUSION}

- We conclude that the CB40 isolate has potential for control of $H$. betulinus, however utilization strategies and the use of adjuvants should be further evaluated to enable field application.

\section{REFERENCES}

AGROFIT, 2015. Disponível em: <http://extranet.agricultura.gov.br/agrofit_cons/principal_agrofit_cons>. Acesso em 20/07/2015.

ALVES, V. S.; ALVES, L. F. A.; QUADROS, J. C de.; LEITE, L. G. Suscetibilidade da broca-da-erva-mate Hedypathes betulinus (Klug, 1825) (Coleoptera: Cerambycidae) ao nematóide Steinernema carpocapsae (Nematoda, Steinernematidae). Arquivos do Instituto Biológico, v. 76, n. 3, p. 479-482, 2009a.

ALVES, V. S.; MOINO JR., A.; SANTA-CECILIA, L. V. C.; ANDALÓ, V.; SOUZA, G. C.; Patogenicidade de nematoides entomopatogênicos a cochonilha-da-raiz-do-cafeeiro Dysmicoccus texensis (Tinsley) (Hemiptera: Pseudococcidae) em laboratório. Arquivos do Instituto Biológico, São Paulo, v. 76, n. 1, p. 67-73, 2009 b.

BARBOSA, C. R. C. Técnicas de produção in vivo de nematoides entomopatogênicos (Rhabditida: Heterorhabditidae) em Galleria mellonela (L.) (Lepidoptera: Pyralidae) e hospedeiros alternativos. $91 \mathrm{f}$. Dissertação (Mestrado em Agronomia/Entomologia), Universidade Federal de Lavras, Minas Gerais, 2005.

BELLINI, L. L.; DOLINSKI, C. Aplicação foliar de nematoides entomopatogênicos (Rhabditida: 
Steinernematidae e Heterorhabditidae) para o controle de Diatrea saccharalis em casa de vegetação. Semina: Ciências Agrárias, Londrina, v. 33, n. 3, p. 997-1003, 2012.

BORGES, L. R.; LÁZZARI, S. M. N.; LÁZZARI, F. A. Comparação dos sistemas de cultivo nativo e adensado da erva-mate Ilex paraguarensis, St.Hill., quanto a ocorrência e flutuação populacional de insetos. Revista Brasileira de Entomologia, São Paulo, v. 47, n. 4, p. 563-568, 2003.

BORGES, L. R. Eficiência de Beauveria bassiana (Bals.) Vuill. (Deuteromycota) para o controle de Hedypathes betulinus (Klug) (Coleoptera: Cerambycidae) em erva-mate, Ilex paraguariensis St.-Hil. (Aquifoliaceae). $101 \mathrm{f}$. Tese (Doutorado em Entomologia) - Universidade Federal do Paraná, Curitiba, 2007.

CASSANEllo, A. M. L. Ciclo de vida e aspectos morfológicos de Hedypathes betulinus (Klug, 1825) (Coleoptera, Cerambycidae, Lamiinae), broca-da-erva-mate (Ilex paraguariensis St. Hil.). 59 f. Dissertação (Mestrado em Entomologia) - Universidade Federal do Paraná, Curitiba, 1993.

D’AVILA, M.; COSTA, E. C. GUEDES, J. V. C. Bioecologia e Manejo da broca-da-erva-mate, Hedypathes betulinus (Klug, 1825) (Coleoptera: Cerambycidae). Ciência Florestal, Santa Maria, v. 16, n. 2, p. 233 - 241 , 2006. Disponível em: $<$ http://cascavel.ufsm.br/revistas/ojs-2.2.2/index.php/cienciaflorestal/article/viewFile/1902 /1148>. Acesso em 12 nov.2011.

FERRAZ, L. C. C. B. Nematóides entomopatogênicos. In: ALVES, S.B. Controle microbiano de insetos. Piracicaba - SP: Fealq, 2ed., 1998, p. 541-567.

FANTI, A. L. P.; ALVES, L. F. A. Isolados de fungos entomopatogênicos visando ao controle da broca da ervamate (Hedypathes betulinus) Kluger (Coleoptera: Cerambycidae). Semina: Ciências Agrárias, Lodrina, v. 34 n. 4, p. 1467-1478, 2013.

FALLON, D. J.; SOLTER, L. F.; KEENA, M.; MCMANUS, M.; CATE, J. R.; HANKS, L. M. Suscetibility of Asian longhorned beetle, Anomoplophora glabripennis (Motchulsky) (Coleoptera: Cerambycidae) to entomopathogenic nematodes. Biological Control, Lexington, v. 30, n. 2, p. 430-438, 2004.

FALlON, J. D.; SOLTER, L. F.; BAUER, L. S.; MILLER, D. L.; CATE, J. R.; MCMANUS, M. L. Effect of entomopathogenic nematodes on Plectrodera scalator (Fabricius) (Coleoptera: Cerambycidae). Journal of Invertebrate Pathology, Urbana, v. 92, n. 2 p. 55-57, 2006.

FERREIRA, D. F. 2011. SISVAR: A computer statistical analysis system. Ciência e Agrotecnologia, Lavras, v. 35, p. 1039-1042.

FINNEY, J. R.; WALKER, C. The DD-136 strain of Neoaplectana sp. as a potential biological control agent for the European elm bark beetle, Scolytus scolytus. Journal of Invertebrate Pathology, Urbana, v. 29, n. 1, p. 7-9. 1977.

FINNEY, J. R.; WALKER, C. Assessment of a field trial using the DD-136 strain of Neoaplectana sp. for the control of Scolytus scolytus. Journal of Invertebrate Pathology, Urbana, v. 33, n. 2, p. 239-241. 1979.

FONSECA, M. G.; VIDAL, D. M; ZARBIN, P. H. G. Male-Produced Sex Pheromone of the Cerambycid Beetle Hedypathes betulinus: Chemical Identification and Biological Activity. Journal of Chemical Ecology, Tampa, v. 36, n. 10, p. 1132-1139, 2010.

GALILEO, M. H. M.; MARTINS, U. R.; MOURA, L. de A. Sobre o comportamento, ontogenia e morfologia do aparelho reprodutor de Hedypathes betulinus (Klug, 1825) (Coleoptera, Cerambycidae, Lamiinae, Aconthoderini) a broca da erva-mate. Revista Brasileira de Entomologia, São Paulo, v. 37, n. 4, p. 705-715, 1993.

GAUGLER, R.; LEWIS, E.; STUART, R. J. Ecology in the service of biological control: the case of entomopathogenic nematodes. Oecologia, New York, v. 109, n. 4, p. 483-489, 1997.

GIOMETTI, F. H. C.; LEITE, L. G.; TAVARES, F. M.; SCHIMIT, F. S.; BATISTA FILHO, A.; DELL'ACQUA, R. Virulência de nematoides entomopatogênicos (Nematoda Rhabditida) a Sphenophorus levis (Coleoptera: Curculionidae). Bragantia, Campinas, v. 70, n. 1, p. 81-86, 2011.

GOMM, P. C.; FURIATTI, R. S.; BARANEK, E.; TLUMASKE, L.; WAGNER, F. O. Eficácia de diferentes dosagens do formulado fúngico à base de Beuveria bassiana (Vuill, 1912) no controle de adultos de Hedypathes betulinus (Klug, 1825) (Coleoptera: Cerambycidae). Revista Acadêmica Ciências Agrárias e Ambientais, Curitiba, v. 8, n. 1, p. 55-60, 2010.

GUEDES, J. V. C.; D’AVILA, M.; DORNELlES, S. H. B. Comportamento de Hedypathes betulinus (Klug, 1825) em erva-mate em campo. Ciência Rural, Santa Maria, v. 30, n. 6, p. 1059 - 1061, 2000. Disponível em: <http://www.scielo.br/pdf/cr/v30n6/a23v30n6.pdf>. Acesso em: 29 nov. 2014.

FLORESTA, Curitiba, PR, v. 47, n. 1, p. 113 - 120, jan. / mar. 2017.

Alves, V. S. et al.

ISSN eletrônico 1982-4688

DOI: $10.5380 /$ rf.v47i1.42965 
HARVEY, C. D.; ALAMMEN, K. M.; GRIFFIN, C. T. The impact of entomopathogenic nematodes on a nontarget, service-providing longhorn beetle is limited by targeted application when controlling forestry pest Hylobius abietis. Biological Control, Urbana, v. 62, n. 3, p. 173-182, 2012.

IBGE, 2014. Produção da Extração Vegetal e da Silvicultura, Rio de Janeiro, v. 28, p. 1-69, 2013. Disponível em: <http://biblioteca.ibge.gov.br/visualizacao/periodicos/74/pevs_2013_v28.pdf>. Acesso em 08 mai 2015.

LEITE, M. S. P.; SOARES, C. M. S.; IEDE, E. T.; PENTEADO, S. R. C.; CASTELLANO, C. Seleção de linhagens de fungos entomopatogênicos para o controle de Hedypathes betulinus (Klug, 1825) (Coleoptera: Cerambycidae) em laboratório e eficiência da linhagem selecionada em campo. Anais... II Congresso Sul-Americano da Erva-Mate e III Reunião Técnica da Erva-mate. Encantado, Ed. dos Organizadores, p. 314-317, 2000.

LEITE, M. S. P.; IEDE, E. T.; PENTEADO, S. R. C.; ZALESKI, S. R. M.; CAMARGO, J. M. M.; RIBEIRO, R. D. Eficiência de Beauveria bassiana (Bals.) Vuill. formulado em óleo no controle de Hedypathes betulinus (Klug) (Coleoptera: Cerambycidae) em campo. Anais... In: IV Congreso Sudamericano de la Yerba Mate, Misiones. Anais... Misiones: p. 269-272, 2006.

MACHADO, L. A.; HABIB, M.; LEITE, L. G.; GOULART, R. M.; TAVARES, F. M. Patogenicity of Heterorhabditis sp. and Steinernema glaseri against larvae of the sugarcane borer root, Migdolus fryanus. In: Latin American Symposium on Entomopathogenic Fungi and Nematodes. Anais... Campos dos Goytacazes. Universidade Estadual do Norte Fluminense Darcy Ribeiro, p. 29, 2003.

MOLINA, J. P.; LÓPEZ, N. J. C. 2001. Producción in vivo de três entomonematodos on dos sistemas de infección en dos hospedantes. Revista Colombiana de Entomología, Bogotá, v. 27, p. 73-78, 2001.

NEGRISOLI Jr, A. S.; BARBOSA, C. R. C.; MOINO Jr, A. Avaliação da compatibilidade de produtos fitossanitários com nematoides entomopatogênicos (Rhabditida: Steinernematidae: Heterorhabditidae) utilizando o protocolo da IOBC/WPRS. Nematologia Brasileira, Campos dos Goitacazes, v. 32, n. 2, p. 111-116, 2008.

PENTEADO, S. R. C.; IEDE, E. T.; LEITE, M. S. P. Pragas da erva-mate: perspectivas de controle. In: II Congresso Sul-Americano da Erva-mate e III Reunião Técnica da Erva-mate. Anais... Encantado, RS, 27-37. 2000.

SÁENZ, A. A; LÓPEZ, J. C. Ciclo de vida y patogenicidad del aislamiento nativo Heterorhabditis sp. SL0708 (Rabditida: Heterorhabditidae). Revista Colombiana de Entomología, Bogotá v. 37, n. 1, p. 43-47. 2011.

SOARES, C. M. S. Flutuação populacional, aspectos comportamentais e levantamento de inimigos naturais de Hedypathes betulinus (Klug, 1825) (Coleoptera: Cerambycidae), em um povoamento puro de erva-mate (Ilex paraguariensis St. Hil.). 73 f. Tese (Doutorado em Ciências Biológicas - Entomologia), Universidade Federal do Paraná, Curitiba, 1998.

SOARES, C. M. S.; IEDE, E. T. Perspectivas para o controle da broca-da-erva-mate Hedypathes betulinus (Klug, 1825) Coleoptera: Cerambycidae. In: I Congresso Sul-Americano da Erva-Mate e II Reunião Técnica do Cone Sul sobre a Cultura da Erva-Mate. Curitiba, Ed. dos Organizadores. Anais...Curitiba, p. 391-400, 1997.

SOARES, C. M. S.; SANTOS, H. O.; IEDE, E. T. Avaliação do parasitismo natural de Eurytoma sp. (Hymenoptera: Eurytomidae) em ovos de Hedypathes betulinus (Klug. 1825) (Coleoptera: cerambycidae). In: CONGRESSO BRASILEIRO DE ENTOMOLOGIA, 15., 1995, Caxambú. Anais... Caxambú, p. 131, 1995.

SOLTER, L. F.; KEENA, M.; CATE, J. R.; McMANUS, M. L.; HANKS, L. M. Infectivity of four species of nematodes (Rhabditoidea: Steinernematidae, Heterorhabditidae) to the Asian longhorn beetle, Anoplophora glabripennis (Coleoptera: Cerambycidae). Biocontrol Science Technology, Lethbridge, v. 11, p. 547-552. 2001.

VAN TOL, R. W. H. M.; VAN DIJK, N.; SABELIS, M. W. Host plant preference and performance of the vine weevil Otiorhynchus sulcatus. Agricultural Forest Entomology, Oxford, v. 6, n. 4, p. 267-278, 2004.

VAN TOL, R. W. H. M.; RAUPP, M. J. Nursery and tree applications. In: GREWAL, P. S.; EHLERS, R. -U.; SHAPIRO-ILAN, D. I. Nematodes as Biological Control Agents. Wallingford, UK: CABI Publishing, 2006.

VOSS, M.; ANDALÓ, V.; NEGRISOLI JUNIOR, A.; BARBOSA-NEGRISOLI, C. R. Manual de técnicas laboratoriais para obtenção, manutenção e caracterização de nematoides entomopatogênicos. Passo Fundo: Embrapa Trigo, 2009. Passo Fundo: Embrapa Trigo, 2009. 44 p. html. (Embrapa Trigo. Documentos Online, 119). Disponível em: <http://www.cnpt.embrapa.br/biblio/do/p_do119.htm>.

WOODRING, J. L.; AND H. K. KAYA. 1988. Steinernematid and Heterorhabditid Nematodes: A Handbook Of Biology And Techniques. Southern Cooperative Series Bulletin 331. FAYETTEVILLE, AR: ARKANSAS AGRICULTURAL EXPERIMENT STATION. 